\title{
REFLEXÓES SUl-AMERICANAS: EM DEFESA DO FILOSOFAR ABAIXO DO EQUADOR
}

\author{
Abraão Lincoln Ferreira Costa ${ }^{1}$
}

\begin{abstract}
Resumo: Com o auxílio do acadêmico e filósofo Julio Ramon Cabrera, o presente artigo desenvolve o estudo sobre uma filosofia desde o Brasil, dividindo-se em três momentos: primeiro, a denúncia contra os efeitos paralisantes causados a partir da colonização europeia, tendo assim obstaculizado há bastante tempo a atividade filosófica, nos países latino-americanos; segundo, a exposição dos elementos teóricos capazes de desconstruir a visão eurocêntrica da Filosofia e, por último, a apresentaçáo da "ética negativa" cabreriana enquanto modelo de um pensar para além do regionalismo. O objetivo dessa investigação é corroborar a viabilidade de produçōes autóctones, cuja qualidade das pesquisas acadêmicas brasileiras garanta, sem qualquer margem de dúvidas, uma profícua interlocução junto aos filósofos já consagrados na tradição ocidental.
\end{abstract}

Palavras-chave: Brasil. Cabrera. Colonização. Ética negativa. Filosofia.

\section{INTRODUÇÁO}

Para que negá-lo? Eu estava estupefato. A clareza da exposição, a lógica dos princípios, o rigor das consequências, tudo isso parecia superiormente grande, e foi-me preciso suspender a conversa por alguns minutos, enquanto digeria a filosofia nova. (ASSIS, Machado. Memórias póstumas de Brás Cubas, 2010, p. 254).

Existe uma Filosofia "desde o Brasil"? A pergunta soaria retórica ou até mesmo desnecessária, caso a destinássemos a qualquer país do Hemisfério Norte,

\footnotetext{
${ }^{1}$ Professor de Filosofia nos cursos de Educação e Direito do Centro Universitário Estácio de Brasília, Brasília, DF - Brasil. (D) https://orcid.org/0000-0002-2963-8943. E-mail: abraaofilosofia@gmail.com.

https://doi.org/10.1590/0101-3173.2022. v45esp.18.p357
} 
contudo, a herança deixada pela colonização europeia torna-a pertinente, haja vista a persistência em dividir opinióes de estudiosos. Vale mencionar Roberto Gomes (2008, p. 11), quando afirma que o brasileiro foge da sua identidade, que, embora "autocomplacente e conformista", jamais "produziu Filosofia" de verdade. Já em defesa do pensar filosófico no país, temos entre vários nomes o de Mario Ferreira dos Santos, o qual considera as próprias ideias como arquitetônicas e únicas, "[...] afrontando, assim, o espírito colonialista passivo de muitos brasileiros, que não admitem e, tampouco, reconhecem a própria capacidade de formularem 'pensamentos próprios'." (SANTOS apud JAIME, 2000, p. 342, v. III).

Disposto a solucionar esse impasse, o artigo tomará posição a favor da existência de um filosofar genuinamente brasileiro. Para bem fundamentálo, é preciso, antes, sintetizarmos as reflexôes do acadêmico e filósofo Julio Cabrera, analisando os motivos pelos quais muitos dos nossos pesquisadores até hoje insistem em desmerecer o potencial e a originalidade da Filosofia latino-americana. Em seguida, mediante os próprios argumentos do autor, desconstruiremos a visão de extremo nacionalismo atribuída aos estudos filosóficos, no Brasil, para somente então desenvolvermos algumas noções de uma "ética negativa" enquanto tese viável que ultrapasse a consideração regionalista costumeiramente dada aos filósofos latinos.

O tratamento oferecido às produçóes filosóficas, no Brasil, quando consideradas dentro do aspecto regional, representam quase sempre a caracterização arbitrária desencadeada pelo errôneo juízo da inferioridade intelectual. Por conta disso, Cabrera (2013, p. 12) retoricamente indaga o motivo de diversos atores do cenário nacional, a exemplo de Artur Orlando, Farias Brito, Jackson de Figueiredo e Mário Ferreira dos Santos, terem desaparecido dos estudos filosóficos, nas universidades. A resposta pode estar no fato de, em vários momentos, os temas advindos dos países intelectualmente ricos ocuparem os espaços das discussôes acadêmicas, tornando-se, consequentemente, responsáveis pelo desaparecimento dos filósofos brasileiros.

O problema não se restringe ao isolamento das diferentes produçóes locais, mas, somado a isso, a cultura europeia aparentemente inoculou dentro dos cursos de Filosofia, no Brasil, o poder de desqualificarem os pensamentos autóctones. ${ }^{2}$ Esse poder, segundo Cabrera (2013, p. 12), tem

2 Sem dúvida, a afirmação soa aparentemente forte, por isso, preciso ressaltar que sigo aqui a visão de Cabrera, sem preocupaçōes mais específicas com qual parte da cultura europeia e como esta realizou o 
a ver com a indução das grandes políticas internacionais promovedoras da miséria intelectual, deixando há muito tempo de ser tratada como um fato natural que congregue um pensamento brasileiro. Ora, em face da aculturação desencadeada pela supremacia branca, surge a pergunta: como produzir pensamentos autônomos, quando o modus vivendi de novas naçóes foi quase inteiramente aniquilado? Parafraseando Einstein, parece um milagre que os métodos científicos e filosóficos dos países ricos sequer tenham completamente estrangulado os métodos sagrados da pesquisa dos diferentes povos.

Por ocasião, esperamos que, logo adiante, não soe contraditória a interlocuçáo realizada entre a filosofia de Cabrera e o pensamento europeizado. Esclarecemos tratar-se de interesse puramente estratégico, a fim de desterritorializarmos algumas das reflexóes ditas "universais", conforme apresentadas pelos filósofos europeus, sobrepondo-as num novo campo de reflexão condizente com a nossa proposta. Desse modo, visualizamos, nas reflexôes do filósofo, desde o balanço crítico até os principais pontos da sua "ética negativa", ambiente apropriado ao fluido diálogo com a tradição filosófica, dando-nos a possibilidade de formularmos a hipótese de que até mesmo a Filosofia europeia viabiliza surpreendentes espaços de entendimento, mesmo aqueles que estejam para além das próprias fronteiras.

\section{Motivos PARA O “NÁO FILOSOFAR"}

São diversos os motivos da incerteza do filosofar desde o Brasil; dentre eles, comecemos pela desconfiança de nossas academias aceitarem, na filosofia franco-anglo-saxônica, a presença de conteúdos fartos de problemas essenciais, sem deixar dúvidas sobre a autenticidade dessas pesquisas. Porém, o pensador sul-americano, na mesma situação dos intelectuais africanos, pondo-se a filosofar, precisa de esforço hercúleo para provar existir o mínimo de sentido em sua exposição e que, dessa forma, ele tem direito a refletir (CABRERA, 2013, p. 12-13). Talvez vejamos nisso motivação suficiente para a insurgência daqueles que filosofam abaixo da linha do Equador: os pensadores não europeus residentes nos países abaixo do Equador precisam marcar posição frente à exclusão intelectual, uma vez que isso os impede de expandirem suas ideias. Isso posto, "[...] filosofar desde a América Latina é reativo e insurgente ou não é; trata-se de uma imperiosa necessidade de sobrevivência." (2013, p. 13).

trabalho de anulação das filosofias autóctones no Brasil e em outros países latinos e africanos. 
Quais seriam as razóes para a permanência dessa suposta submissão? As queixas são inúmeras, considerando o fato de tanto brasileiros quanto afros e demais latino-americanos jamais integrarem o respeitável universo de estudos, programas de pesquisa e ementas de Filosofia. Na verdade, boa parte do que é feito filosoficamente costuma ser mais do interesse de especialistas acostumados a comentar os filósofos estrangeiros, e que se tornam um estudo marginalizado, no caso de resolverem escapar dessa estratégia subserviente. Como brasileiros, é inegável o reconhecimento mundial de certos pesquisadores, graças às contribuições da Sociologia de Florestan Fernandes, a Geografia de Milton Santos, a Antropologia de Darcy Ribeiro, a Historiografia de Sérgio Buarque de Holanda e a Pedagogia de Paulo Freire. Mas quais os impedimentos para o filosofar, desde o Brasil? Contrariando a própria pergunta, reiteramos acreditarmos numa filosofia brasileira; no entanto, a resposta para a tímida repercussão dos seus estudos estaria, além de outros motivos, no desconhecimento "[...] da língua portuguesa por parte de hispano-falantes, e da língua espanhola por parte de brasileiros" - algo que, sendo solucionado, possivelmente abalaria o eurocentrismo filosófico (CABRERA, 2013, p. 16).

Dominar e propagar a língua materna já é uma hipótese defendida por filósofos, como Friedrich Nietzsche. Para ele, qualquer formação de excelência, incluindo a autonomia do pensar, encontra-se na dedicação à língua materna, pois somente através dela vemos a mais alta manifestação da força vital de um povo. "Levem sua língua a sério! Aquele que não chega ao sentimento de um dever sagrado para com ela, este não tem mais em si o germe que convém a uma cultura superior." (2003, II). Todavia, apesar de Nietzsche recomendar a leitura dos clássicos antigos, nós nos permitiremos, conforme sinalizamos, deslocar esse entendimento na direção de outro propósito mais conveniente a nós. Para isso, divergimos de Cabrera (2013, p. 16), por acreditarmos que a questão da língua materna não é secundária. Ao retomarmos a observação do filósofo alemão, presumimos que, se o aprofundamento das línguas grega e latina jamais o tornaram intelectualmente submisso, tampouco o reduziram a um simples comentador do pensamento grego, então, por qual razão isso aconteceria conosco? Convenhamos que os problemas enfrentados pelos pesquisadores latinos são mais oriundos da violência, durante o processo de colonização e aculturação - ao contrário da sedução casuística das línguas estrangeiras. 
Cabrera condena a existência de afirmaçóes normalmente irrefletidas, a respeito de as filosofias europeias serem consideradas universais e, portanto, superiores aos pensamentos essencialmente latinos. É mister averiguar, nesse discurso, certa manobra política disposta a perpetrar a hegemonia da raça branca associada à ideologia da certeza de o mundo ter alcançado, através dos pensadores europeus, a verdade objetiva e absoluta (CABRERA, 2014, p. 2-3). Tendo a mesma impressão, Willian Ospina (2013, p. 26) declara ter perdurado desde a ocupaçáo luso-espanhola nas Américas uma ideologia colonialista, reverberando principalmente nas práticas pedagógicas que ensinam arte, ciência, religiáo e filosofia europeia como produtos universais. Desta feita, nada mais apropriado do que o uso de outra postura marcadamente política, visando a combater os excessos cometidos há mais de quatro séculos, nas instituiçôes de ensino latino-americanas. Em artigo publicado pela revista Nabuco, "Europeu não significa universal. Brasileiro não significa regional", Cabrera contextualiza:

\begin{abstract}
A respeito de filosofia no Brasil, muitos dos que tomam parte em discussóes estão totalmente convictos de que a produção filosófica europeia representa pura e simplesmente o pensamento universal, enquanto colombianos, brasileiros ou africanos, quando pensam os problemas que surgem de suas realidades, refletem a partir de suas procedências nacionais e náo fazem autêntica filosofia universal. Pensam que quando alguém fala em "idealismo alemão" refere-se a algo destinado à humanidade, mas que quando alguém fala em "filosofia brasileira" não expressa nada que tenha sentido. Esses pensamentos são tão controversos, tão insatisfatoriamente pensados e tão apressadamente formulados, que não vale a pena discutir com alguém que esteja tão convicto dessas ideias a ponto de não mais estar disposto a colocá-las em discussão, escutar contra-argumentos e, se for o caso, mudar de postura. (CABRERA, 2014, p. 2).
\end{abstract}

O filósofo latino descreve os motivos de existir uma falsa convicção, no filosofar brasileiro, pelos seguintes motivos: a) a filosofia na funçáo de generalizar os temas e as respostas confirma nos europeus sua legítima vocação, já que o seu conjunto de ideias trata do entendimento humano de forma independente e desprovida de "idiossincrasias regionais"; b) a história da filosofia na Europa corrobora o primeiro argumento; c) países africanos e latino-americanos jamais conseguiram alcançar um pensamento livre e universal; d) a expressão "filosofia no Brasil ou na Colômbia ou em Gana" contradiz o intento da universalidade oriundo da própria filosofia; e) as categorias do pensar filosófico pertencem exclusivamente aos países do 
Hemisfério Norte, daí a pretensão de brasileiros e demais sul-americanos se rebelarem soaria contraditória, devido à base inicial de qualquer crítica contra a filosofia europeia acabar invariavelmente dependente dela; f) como ramificação do argumento anterior, só é possível estabelecer comparaçôes com a filosofia europeia; g) para os pesquisadores africanos e latinos, é impossível o pensamento autoral, sem pressupor como condição sine qua non o amplo conhecimento do "acervo de conhecimentos filosóficos universais", sendo que qualquer pensamento na contramão disso esteja fadado a dois caminhos: a repetição ou a ingenuidade (CABRERA, 2014, p. 4-5).

Mantendo-nos alinhados às consideraçóes do autor, desta vez seguiremos para os argumentos voltados à desconstrução dos pré-conceitos antes mencionados. Pensando no melhor início e cumprimento desse propósito, torna-se precípuo analisar de diferentes maneiras o que é Filosofia brasileira e o que erroneamente significa "não haver" Filosofia brasileira.

\section{EM DEFESA do FILOSOFAR ABAIXo do EQUAdor}

Cabrera destaca, na primeira explicação sobre aquilo que é Filosofia brasileira, o problema da inversão cometida pelos acadêmicos, ao acreditarem saber "por demais" as diferentes respostas. O problema dessa certeza seria o fato de vários pesquisadores de Filosofia, no Brasil, partirem de padróes idênticos entre si, frequentemente difusos na comunidade acadêmica internacional. Sua argumentação prossegue, propondo desconstruir esse entendimento, deixando, dessa forma, de enxergar a Filosofia como "uma coisa só", amplamente conhecida. Como o próprio autor explica:

Pode-se vincular o filosofar com o desamparo da finitude, seja qual for o âmbito em que a reflexão se manifeste, seja na Filosofia da Matemática ou na Filosofia da existência. Nesta visão, o caráter filosófico não se adquire mediante a apropriaçáo dos tecnicismos do pensamento, mas com o próprio ser no mundo. E, de acordo com ela, todos somos filósofos. Num segundo pensamento, porém, nem todos somos filósofos, apenas aqueles seres perguntantes que não só vivem as suas inseguranças insatisfeitas, mas as transformam numa forma de sensibilidade para o esclarecimento. (CABRERA, 2013, p. 21).

Nos últimos tempos, especialmente no Brasil, a Filosofia assume caráter profissionalizante e instrumental. No instante em que insiste em 
permanecer dentro desse formato, acaba tornando seus estudiosos limitados aos seus procedimentos, desprovidos de originalidade e da autonomia. Essa profissionalização do ensino da Filosofia tende a não criar nada de novo, considerando simplesmente reproduzir o que no passado fora pensado, ignorando a fragilidade e o desamparo típicos daquilo que emerge a cada momento, em nosso diário viver. É preciso reconhecer, no pensar e no indagar, manifestaçôes constitutivas e impulsionadas "pelo simples fato de ser" e, nesse aspecto, todo o pensar filosófico merece estar num lugar aquém da aviltante apropriação dos ambientes acadêmicos (CABRERA, 2013, p. 22).

Pertencer à condição de humano remete invariavelmente à capacidade de refletir, mesmo das maneiras mais elementares possíveis, condição sem dúvida pertencente à forma de saber da qual se satisfaz, produzindo inquietaçôes nos seres humanos. Por isso, o ato de filosofar não está meramente preso ao acúmulo de informaçóes, aliás, pode inclusive negá-las, adotando procedimentos de desconstrução e de desinformação, contentando-se com reflexôes mínimas, sem dar importância à quantidade de dados. Isso nos leva à crença de que nenhum filósofo se constitui pela razão de saber mais, "[...] mas de 'ser mais' mediante uma indagação sobre o mundo." E, a despeito da erudição desse filósofo, isso nunca deve fazê-lo "[...] esquecer da carência fundamental que o constitui, e que não demanda preenchimento ou satisfação, mas simples consumação numa forma de existência.” (CABRERA, 2013, p. 22).

Obedecendo a esse raciocínio, a Filosofia, segundo Cabrera, adquire exuberância devido à chance maior de variação, de expansão e de autocriação. $\mathrm{O}$ expansionismo e a diversidade caracterizam o pensamento filosófico, ao invés de rotulá-lo como algo estritamente racional ou universalizante. Afinal, será preciso acompanhá-lo, para verificar os meios pelos quais se desenvolve e também como é mantido, diante do pluralismo de ideias que eventualmente venham a comprometê-lo. Em suma, Cabrera (2013, p. 22) define "o que é Filosofia" como a forma de conhecimento possuidora de natureza múltipla, propiciando a aparição de diferentes textos, quer orais, quer escritos, chamados de "filosóficos", independentemente de serem textos lógicos, epistemológicos, éticos ou existencialistas. O importante é reconhecermos, na multiplicidade do filosofar, o desdobramento da sua essência, diferentemente de uma concepção histórica enrijecedora, preocupada com localizá-lo e defini-lo, mediante critérios do paradigma europeu.

Prevenindo-nos contra os riscos de leituras mais desatentas, esclarecemos que o novo sentido filosófico em hipótese nenhuma é reduzido a alguma 
espécie de laissez faire, pois, seguramente, nem todo pensamento é filosófico. Contudo, entáo, o que o torna filosófico? Decerto, pensar filosoficamente não implica, com rigor, apresentar, enunciar algo inédito, inusitado. É, portanto, dispensável certo inquirimento intelectual obcecado em dar à luz aquilo que ainda não foi pensado. "Uma das coisas que o filósofo, instintivamente, 'escolhe' é o particular nível de 'profundidade' em que seu pensamento será capaz de desenvolver." (CABRERA, 2013, p. 22). Isso requer autonomia e liberdade, para encontrar o ambiente que lhe pareça o mais adequado. Suas ideias estarão destituídas da ambição da novidade e da universalidade, tendo em vista a autenticidade do pensamento ignorar as trivialidades - cabe o exercício de pensar livremente, independentemente daquilo que o mundo possa enxergar. Não vislumbramos nisso a vulgarização do fazer filosofia, mas de apenas inseri-la dentro de critérios mais amplos do que as definiçóes fixas, responsáveis por estabelecê-los como legítimos ou ilegítimos.

Cabe salientar a ocorrência de diversos debates na própria tradição filosófica referentes à autenticidade do ato de filosofar. Prova dessas disputas pode ser facilmente encontrada nos estudos do Círculo de Viena. Alguns filósofos, como Rudolph Carnap, defendem que as questóes filosóficas são unicamente aquelas que perpassam uma ampla e rigorosa análise lógica, fundamentadas numa estrutura argumentativa que esteja principalmente caracterizada pela veemente oposição às ideias metafísicas especulativas (LOSEE, 2000, p. 196). Nesse aspecto, seguramente contrário à tese de Cabrera, Carnap e os demais membros do círculo vienense adotam a utilizaçáo de critérios delimitados, tornando, dessa forma, excludente todo e qualquer argumento insuficiente de contemplar as regras lógicas e analíticas.

O perigo continuará, caso ignoremos a distinção entre a tese de Cabrera e aquilo que ainda há pouco chamamos de laissez faire. A multiplicidade do pensar não pode nos levar à imprecisão, durante a tentativa de denominarmos o que seja ou náo Filosofia. Antes de tudo, lembremos que, independentemente da visão múltipla, a Filosofia nunca poderá abrir mão da profundidade do pensar e dos seus fundamentos. O pensamento filosófico envolve certa atitude, em geral, inovadora, sujeita à crítica e à transformação, devendo ser um conhecimento que se recuse a operar dogmaticamente, desvencilhado da preocupação de proteger o ambiente tradicional. O novo filosofar consiste na elaboração de teorias deveras ou de fato dispostas a suspeitarem dessa tradição, desenvolvendo outras tradiçóes sempre abertas ao constante devir dos pensamentos. Sobre isso, resumindo: 
A atividade filosófica é, para mim, impiedosa, incisiva e sem perdão e vai até onde as suas categorias a conduzam. Uma Filosofia poderá abalar os valores que sustentam a nossa sociedade, ou poderá, inclusive, destruir seu próprio sustentador. É uma tarefa perigosa, cujos desfechos não podem ser previstos. (CABRERA, 2013, p. 25).

Deleuze e Guattari (1992, p. 46) veem no devir e na multiplicidade o resultado do estatuto pedagógico do conceito, sendo compreendido pela capacidade de realizar variaçóes e ressonâncias desconhecidas. Acolhida essa explicação, os conceitos se mostram de pleno pertencimento da Filosofia, porque esta é a forma de conhecimento criadora, responsável por erigir novos eventos, através do espaço, do tempo, da matéria e do pensamento. Logo, a força da Filosofia consiste na avaliação da "[...] natureza dos acontecimentos aos quais seus conceitos nos convocam, ou que ela nos torna capazes de depurar em conceitos." (DELEUZE; GUATTARI, 1992, p. 47). Daí a importância de os filósofos experimentarem pormenorizadamente a ligação única, exclusiva, dos conceitos com o saber filosófico enquanto conhecimento criador. Com isso, acreditamos que a filosofia deleuziana náo apenas dialoga com as ideias de Cabrera, como as corrobora, em função de ambas convergirem num conjunto de reflexóes, que, a despeito das variaçóes estilísticas de cada pensamento, pertencem ao âmbito do saber filosófico.

Ora, seria correto dizermos que os aspectos delineadores do pensamento de Rudolf Carnap são idênticos aos de Sören Kierkegaard? Nós, e também Cabrera, suspeitamos da credibilidade desses filósofos, seja pela falta de elementos históricos e existenciais do filósofo analítico, seja pela falta de rigor argumentativo do filósofo existencialista. A coerência sustentada no argumento do autor latino é o motivo de ambos serem considerados filósofos praticamente sem rígidos questionamentos (CABRERA, 2013, p. 27). Nesse caso, por que não faz sentido os pesquisadores latinos desenvolverem Filosofia de diferentes formas, acolhendo as especificidades de suas respectivas culturas e pensamentos? Vê-los pensar sem coaçóes de cunho estilístico ou metodológico, exercendo o pleno direito de pensarem filosoficamente? Outrossim, a resposta para "o que é Filosofia" está sintetizada na variação ininterrupta entre um pensamento mais estruturado e outro mais histórico, ou entre a circunspecçáo lógica do argumento e as experiências de vida. Aceitando isso, o que ainda nos impediria de filosofar, no Brasil? Sigamos adiante, para descobrirmos os obstáculos. 
Num sentido estrito, as academias brasileiras consideram sem a menor chance a consolidação de uma "Filosofia nacional", ou de uma "Filosofia brasileira" (CABRERA, 2013, p. 27-28). As explicações partem da impossibilidade de aceitarem pensamentos cujo intuito sintetiza nossa maneira de ser, limitando-nos a explorar temas nacionais, removendo, por conseguinte, a Filosofia do seu caráter universal. Desse ângulo, não veríamos tanta objeção, todavia, admitindo-se que um filósofo pensa "desde o Brasil", jamais significa achar que esteja fazendo exclusivamente "Filosofia brasileira", mas sim a mesma Filosofia aceita mundo afora. Por que a originalidade do filosofar do brasileiro Farias Brito é menos admitida em relação ao filosofar dinamarquês de Kierkegaard ou do filosofar escocês de Hume? Nietzsche, em obras como o Nascimento da Tragédia ou nas Consideraçóes extemporâneas, não se deteve à crítica e à revitalização somente da cultura alemã? O que torna suas denúncias contra as instituiçôes de ensino na Alemanha mais universais, quando comparadas com a abordagem histórico-crítica de reflexóes como as de Dermeval Saviani?

Precisamos nos posicionar a respeito do assunto, pois acreditamos que o problema jamais partiria da rejeição formal das Universidades às produçóes filosóficas locais. Seria, certamente, imprudente tanto da nossa parte quanto da parte do próprio autor afirmar categoricamente que os cursos de Filosofia no Brasil abertamente censuram seus alunos e professores de estudarem os filósofos latinos e africanos. Ademais, é pertinente esclarecermos que a questão aparenta ter mais a ver com os efeitos ideologizantes da cultura europeia sobre os países do Hemisfério Sul, levando-os apenas a estudá-la, embora a filosofia cabreriana não tenha nenhum interesse de vincular-se a qualquer corrente marxista.

Cabrera oferece a oportunidade de dissolução da dicotomia entre Filosofia e nacionalidade. Porém, o problema persiste, devido à necessidade de aprendermos a diferenciar "Filosofia no Brasil" e "Filosofia desde o Brasil". Para melhor esclarecimento, o filósofo (2013, p. 29) mostra a importância de distinguirmos as preposiçóes "no" e "desde". A começar pela preposição "no", devemos entendê-la como mera atividade filosófica, feita no país, através de estudantes e professores, e somente nela é possível admitir todos os aspectos ideológicos, geográficos e nacionalistas. Entretanto, quando nos reportamos à preposição "desde", percebemos, em seu uso, alusão à vitalidade e à reflexão, tendo a ver com a habilidade de "produzir conceitos", sem estarmos presos ao trabalho exegético de decifrar outros filósofos: 
Filósofos que pensam "desde" o Brasil farão simplesmente Filosofia (e não "Filosofia brasileira"), mas não farão Filosofia que qualquer outro poderia ter feito desde qualquer outro lugar, nem farão meros comentários sobre Filosofias feitas em outros lugares. Não serão, pois, nem comentadores ultrapessoais ("pensadores nacionais") nem pensadores impessoais ("técnicos da Filosofia", como é hoje recomendado), mas filósofos pessoais: eles terão apresentado em seus textos a sua pessoa filosófica, a sua procedência de pensadores. (CABRERA, 2013, p. 30).

Reconhecer a diferenciação das preposiçôes "no" e "desde" aumentaria as esperanças de existir e de terem existido filosofias tão universais, no país, quanto em qualquer lugar da Europa. A questão fulcral está mais ligada ao problema dos mecanismos de divulgação e reconhecimento das pesquisas autorais, ao invés da falta de talento e de inventividade dos pesquisadores brasileiros. Mitigar esses efeitos paralisantes depende da maior atenção das universidades e do mercado editorial com aqueles que filosofam "desde o Brasil”. No entanto, na contramão desse incentivo, Cabrera (2013, p. 31) denuncia a manutenção de uma mentalidade sabotadora do filosofar. Se, por um lado, notamos o grande aparato de publicaçóes, eventos e bibliografias dos trabalhos filosóficos europeus e norte-americanos, em nossos departamentos, por outro, é bem mais difícil identificarmos as contribuiçóes filosóficas originais.

Caso alterássemos os critérios determinantes daquilo considerado como "ser" ou "não ser" Filosofia, teríamos, talvez, boas chances de descobrir e valorizar os nossos filósofos. Para tanto, caberia repensarmos os efeitos da profissionalização da Filosofia, que desconhece o filosofar "desde o Brasil". Portanto, insistimos na relevância de destacarmos a singularidade fartamente encontrada nos pensadores consagrados, tendo em vista as disparidades de suas ideias interferirem minimamente no reconhecimento de seus pensadores. "O pensamento surge da própria vida do filósofo, tanto de seus desgarramentos pessoais quanto de suas perplexidades intelectuais, inseparáveis uns dos outros." (CABRERA, 2013, p. 33).

A singularidade na ação filosófica desencadeia rupturas com os meios existentes, devido à vontade de o pensamento manifestar sua interpretação acerca do mundo. Esse acontecimento varia, a partir dos aspectos lógicos, ontológicos, éticos, estéticos, gnosiológicos ou religiosos. Embora um filósofo sofra a interferência sociocultural comum do seu tempo, isso seria insuficiente para engendrar um pensamento verdadeiramente filosófico. Por 
esse raciocínio, se, de fato, não existem filósofos "desde o Brasil”, não será apenas por culpa das "condiçóes sociais e culturais" inadequadas, mas também e, principalmente, pela falta da singularidade. $\mathrm{O}$ ato singular de filosofar é composto de intencionalidade e pontualidade, surgindo independentemente da época e do lugar. Todavia, como ativar essas forças no filósofo? A tradição é farta em nos dar explicaçóes. Lembremo-nos da thaumásia grega, contida no "espanto" aristotélico ou na situação-limite de Jaspers, em que o indivíduo vive uma situação dramática na qual é posto e nela não suporta mais permanecer.

Muitos foram os estímulos sugeridos para começarmos um pensamento genuinamente filosófico. A contribuição de Cabrera (2013, p. 35) ao tema sintetiza a sensibilidade associada à vontade de querer filosofar, sujeita aos riscos e à responsabilidade de enfrentar as consequências de nossas próprias ideias. Em síntese, a sua tese é de que um filósofo não surge automaticamente de uma prática social e muito menos de um meio social favorável ou desfavorável. O segredo para tornar-se um bom filósofo exige a acuidade no trajeto das experiências pessoais, aliada à vontade de explicitar seus pensamentos pelo exercício da escrita e da oralidade. Tal treinamento o credenciará a pensar em apoio ou oposição às práticas vigentes, entretanto, mesmo que isso propicie uma influência sociocultural do seu tempo, não deverá ser levado a sério, considerando que o próprio ato de filosofar depende muito mais das forças que o indivíduo traz consigo do que das circunstâncias externas e temporais que possam motivá-lo.

Passemos para a próxima explicação sobre o que significa "não haver" Filosofia, no Brasil. Retomando o argumento mostrado em defesa da pluralidade de pensamentos na tradição ocidental, constatamos a abrangência de várias temáticas. Podemos identificar alguma similitude entre os diálogos platônicos com os escritos kantianos? O que dizer de Plotino em relação a Wittgenstein? Caso reconheçamos nessas diferenças a incerteza de critérios que categoricamente afirmem a definiçẫo do que seja ou não "Filosofia", também reconheceríamos a precipitação das declaraçóes de que "não há", nunca houve nem haverá filósofos no Brasil. Pretenso a desmontar essa má impressão, Cabrera (2013, p. 45) desenvolve sua explicação dividindo a negativa do "haver" em três tempos verbais: "não houve", "não há" e "não haverá".

A respeito do "não houve" Filosofia?, na criação das universidades, percebemos o interesse histórico de implantar ideias fortemente aceitas em outros lugares. O problema disso costuma ser o exagero dessa implantação. Se pensarmos nos positivistas brasileiros e no quanto resolveram pensar 
de acordo com as ideias de Augusto Comte, concluiremos ter restado pouquíssima margem para discussão de ideias complementares ou inovadoras. Em complemento a essa impressão, ousamos inferir, acerca de alguns cursos de Filosofia, no Brasil, nunca terem incentivado seus estudantes a pensarem de maneira original. A resposta pode estar no fato de estudiosos, consagrados por interpretarem filosofias do tipo cartesiana, espinozista, nietzschiana e tantas outras, terem precisado ou resolvido ingressar em programas internacionais, o que numa certa medida os teria distanciado das comunidades brasileiras, ao comentarem pensamentos de pouquíssima utilidade pública.

Nesse sentido, as universidades acabam se restringindo à formação de bons comentadores e especialistas, preocupados em atender às regras devidamente institucionalizadas, as quais precisam rigorosamente serem internalizadas, através de acadêmicos que buscam alcançar uma carreira de prestígio (CABRERA, 2013, p. 47). Resta aos ambientes universitários debaterem ideias e compartilharem desejos e reflexóes com outras pessoas também interessadas por temas filosóficos. Logo, as dissertaçóes de Mestrado ou as teses de Doutorado precisam atender às normas estabelecidas pelos cursos e departamentos, isto é, promover um trabalho exegético, para que, no final, consigam provar que sabem interpretar fielmente qualquer coisa que algum pensador consagrado já havia pensado.

Sobre o "não há", Cabrera (2013, p. 64) menciona o esforço, na primeira metade do século XX até o presente, de produzir Filosofia sul-americana, de maneira mais pessoal. Náo obstante, qualquer tentativa de um pensamento singular tende a ser sufocada pela acusação injusta de faltar fundamentos e seriedade. Ora, mas por que isso acontece? O intuito de conter o pensamento brasileiro aponta no rumo das motivaçóes políticas. Para o autor, uma atividade filosófica é definida por sua imprecisão e falta de contornos bem delimitados e, precisando manter-se, encontra na conveniência da interpretação filosófica europeia o "porto seguro" que lhe garanta verbas e demais incentivos para as publicaçóes científicas. "É claro que a padronização de procedimentos técnicos é muito mais 'produtiva' que a criatividade autoconstituinte." (CABRERA, 2013, p. 69). Diante da situação, o destino do professor de Filosofia é bem semelhante ao de um trabalhador servil, sobrecarregado de demandas administrativas e pedagógicas, restando a ele pouquíssimas oportunidades de pensar e desenvolver projetos que sejam considerados originais.

Por último, o "não haverá", invariavelmente, nos leva a deduzir que, seguindo os argumentos do "não houve" e do "não há", tornar-se-á improvável 
o florescimento do filosofar brasileiro. Cabrera relata as inúmeras frustraçóes dos jovens estudantes de que acabam depois de vários semestres sofrendo reprimendas de um programa cultural europeu e sistematizado (CABRERA, 2013, p. 70). Apesar dos obstáculos apresentados, o modelo vigente, mesmo assim, aparenta dar sinais de rupturas, motivo pelo qual se elevam cada dia mais novas críticas contra a forma do ensino da Filosofia, no Brasil. Como prova disso, exibiremos os principais pontos da "ética negativa" cabreriana, procurando mediante esse estudo ilustrar um pensamento suficientemente íntegro e autêntico, que, pela falta de melhor significado, resolvemos qualificálo como universal.

\section{3 ÉTICA NEGATIVA: POR UMA FILOSOFIA DESDE O BRASIL}

Um bom começo para a explicação da "ética negativa" está no esforço preliminar de desconstruirmos certos entendimentos relacionados ao propósito e ao valor da vida humana. Numa linha semelhante ao pessimismo schopenhauriano, o filósofo latino propôe a inversão da compreensão de pressupostos acerca de um mundo belo, próspero e feliz. Tanto Cabrera quanto Schopenhauer compartilham da impressão de haver enorme diferença, quando contemplada a beleza do sol, dos vales e das montanhas, em face daquilo que verdadeiramente somos. A esse respeito, é equivocado darmos à vida projeçóes incertas, partindo de desejos incondizentes com a realidade e, portanto, ineficazes no combate às angústias e às incertezas humanas. Para a correta noção do que vem a ser a ética negativa, Cabrera desenvolve inicialmente uma investigação da condição do ser humano, buscando chegar às seguintes certezas: primeiro, a importância de inverter os valores entre nascer e morrer e, segundo, o reconhecimento da vida humana como dolorosa e antiética.

Pautado num argumento denominado "articulação ética fundamental", Cabrera explica a diferença de aceitar a vida como básica e contingente para o valor que de costume lhe fora atribuído. No entanto, o autor discorda da existência de um pressuposto valorativo na vida humana, já que, em matéria de filosofia, a existência requer o exercício da consciência, esperando dar-se conta da problematicidade do seu valor, sem ser confundida com motivaçóes emotivas ou religiosas. $\mathrm{O}$ verdadeiro acréscimo de valoração à vida depende do reconhecimento da nossa mortalidade. Dessa maneira, a morte passa a valer intrinsecamente, tanto no plano sensível quanto no plano moral, sendo subdividida de forma pontual e estrutural. A morte pontual significa 
o desaparecimento factual ou a interrupção literal das açôes (percepção, movimento, desejo e cumprimento de tarefas), enquanto a morte estrutural está ligada ao sentido de nascer e às repercussôes, em nível ontológico, do nosso deixar de existir (CABRERA, p. 133-134).

A tendência das éticas afirmativas seria simplificadamente enxergar na morte pontual o fim da possibilidade da realização dos desejos, ao passo que a morte estrutural demonstra as vantagens do nascimento, depreciando o acontecimento da morte. Ao seguirmos a ética negativa, faz-se apropriado identificarmos, na morte pontual, a vantagem de nos livrarmos de determinados sofrimentos, como a doença, a velhice, a miséria e as desilusôes. Por esse prisma, a morte assumiria sentido positivo e a vida, negativo. Aceitando essa inversão, a morte estrutural, antes vista como acontecimento ruim, comparada à beleza do nascimento, transforma-se num acontecimento afirmativo, tendo em vista o nascer que passa a representar algo desvantajoso, pela inserção neste mundo carregado de dores e incertezas. A mudança ou equiparação entre os valores da vida e da morte abre horizonte para a conclusão de o homem, enquanto ser no mundo, contrair na maior parte do tempo situaçóes desconfortantes e moralmente insatisfatórias, obtendo na morte o remédio contra o sofrimento.

$\mathrm{Na}$ filosofia de Lucrécio, a morte é o fenômeno que, durante a vida, sequer existe, e, ao morrermos, deixaremos de nos preocupar com o viver. Esse desencontro entre vida e morte sugere a desmitificação da imagem negativa da finitude, embora o raciocínio do pensador e poeta romano só faça sentido na ótica de uma morte pontual, porém, refletido a partir da morte estrutural, isto é, reconhecendo a incompletude do nosso ser, através das decepçóes, dos danos causados aos outros, a nós mesmos e das desilusôes. Trata-se de experimentar o desgaste existencial, como se estivéssemos morrendo em razão de cada triste acontecimento. Em suma, “[...] perder, desocupar, retroceder, degradar-se, são estados que não podem ser vividos positivamente," mesmo que pudéssemos suportá-los ou nos adaptarmos a eles (CABRERA, 2013, p. 138). Desta feita, a definição de "mau” está relacionada com algo sofrível, levando-nos à certeza de que a morte estrutural seria deveras ruim, embora internamente constitutiva da vida humana, já que não existe ninguém ausente do sofrimento. Assim, entendendo a morte estrutural como má, concluiremos que a vida humana é ontologicamente ruim, em função do desconforto que acompanha os seres humanos, em vários momentos. Cabrera, portanto, indaga: 
Como é possível não desconsiderar má a decadência progressiva, a inibição de nossas possibilidades e o sofrimento terminal? Como o agnóstico pode dizer sem crueldade ou ignorância que o envelhecimento crescente e irreversível de nosso cérebro é algo sensivelmente "nem bom nem mau? (CABRERA, 2013, p. 139).

Comumente, alegamos a naturalidade dos acontecimentos ruins da existência, mas isso jamais reduziria o valor do desagrado ligado ao sensível - uma naturalidade, sem dúvida, incapaz de mitigar as dores da perda. Destarte, não bastam posturas ocultantes, nos diferentes extremos das explicaçóes metafísicas ou agnósticas - com o sofrimento inerente à condição de seres humanos é quase sempre difícil de lidar. Temos, assim, de desafiar a aflição da consciência da morte estrutural, incapazes de evitá-la, restando-nos aprender a suportar os abalos provocados por traiçóes, perdas dos entes amados, enfermidades e demais infortúnios. A depender da ética negativa, há fortes divergências a respeito do epicurismo de Lucrécio, pois náo ocorreria o desencontro com a morte, contudo, pelo contrário, ela se faz constante, a partir da perspectiva simbólica de uma morte estrutural, indissociável da vida humana.

Ao mostrar esses argumentos, Cabrera conclui os riscos da inabilidade moral resultante da verdadeira estrutura ontológica que os homens trazem consigo, ou seja, da existência de uma dor estrutural inerente ao ser. A banalidade do cotidiano, associado às constantes exigências da sobrevivência, num plano de incertezas, leva ao questionamento das condiçóes de levarmos a todo momento uma vida inteiramente moral. Pautados nessa questão, perceberemos o quanto é difícil adotarmos uma postura ética, na mesma intensidade, acompanhando-nos nas diferentes circunstâncias temporais. Nesse ângulo, mesmo corretamente empenhados em adotar uma postura ética, será provavelmente inevitável que, num determinado momento, devamos “[...] mentir, enganar, trair, tentar chegar antes, deixar os outros pelo caminho etc, na estrita medida em que desejamos continuar vivendo." (CABRERA, 2013, p. 143). Esse comportamento ocorrerá em razão dos mesmos motivos de tentarem nos enganar, trair, incomodar, ridicularizar e agir de outros modos, intencionando nos prejudicar.

Sob o risco de incorrermos na desatenção de interpretarmos Cabrera como um filósofo antiético, chamamos atenção para a importância da flexibilizaçáo dos princípios morais, enquanto meio de nos afastarmos do 
excessivo comportamento moral. Gestos eticamente escrupulosos vivem em constante perigo, na estrutura do mundo, a qual pode levar qualquer pessoa que os adote à loucura, ao ridículo, à destruição ou à perda de oportunidades. Apesar do exemplo fictício, destacamos o filme Viridiana, do cineasta hispano Luis Buńuel. Sua história conta as desvantagens da adoção de princípios exageradamente cristãos, por isso, destituídos do bom senso, para avaliar as consequências das açôes da protagonista. $\mathrm{Na}$ obra, além da integridade física, a integridade moral da protagonista é abalada, carecendo do uso da flexibilidade para a manutenção da vida e dos princípios. "Se assim não o fizermos, a nossa estrutura psicológica ficará abalada e nos castigará com depressóes e angústias, pois a nossa personalidade é constituída sobre os nossos triunfos sobre os outros." (CABRERA, 2013, p. 144).

Esse apanhado de ideias procura justificar o implemento da ética negativa, mas sua força francamente depende da capacidade de aprendermos a "deflacionar" a carga valorativa pertencente à moral afirmativa. O comportamento negacionista requer permanente indagação de outras atitudes que, de costume, ocultam os fatos radicais comuns da condição humana. É como se o filósofo nos dissesse que a adoção de certas medidas morais ou simplesmente afirmativas fosse de encontro com a verdadeira estrutura ontológica ligada à nossa constituição. Desejosos pelo sucesso desse projeto, será preciso nos convencermos de haver pouquíssimo valor na vida humana e, frente à natureza, admitirmos não passar de seres insignificantes, sem que ninguém senáo nós mesmos sejamos responsáveis por nossas oscilaçóes psíquicas. É aconselhável um comportamento simples, distanciado e renunciante, além de reflexivo e tolerante. O objetivo disto será

[t]ornar os humanos mais pessimistas e melancólicos, menos exuberantes, menos esperançosos, menos ansiosos de "viver intensamente". Uma espécie de educação negativa da humanidade num viés anti-Schiller. Uma ética deste tipo deveria também explicitar o que mudaria, numa postura negativa, na nossa atual atitude perante os fenômenos vinculados com a vida-morte, notadamente o "heterocídio" e outras questóes correlatas (suicídio, procriação). (CABRERA, 2013, p. 148).

Aceitando a dor como fenômeno subjacente à espécie humana, Cabrera propóe o afastamento da cobertura ontológica anteriormente responsável pela falsa aparência da nossa proteção. Para tanto, cabe refletirmos constantemente sobre a tarefa de admitir a própria miséria existencial e seu amplo desregramento. Reconhecer o próprio desamparo onde vivemos, sob a constância dos 
perigos e das ameaças, também pode nos levar à certeza da inexistência do universal. Essa crítica endereçada a certas teorias postuladas pelas éticas europeias tende a oferecer mudanças consideráveis em assuntos referentes ao suicídio e à procriação. Embora longe de explorarmos pormenorizadamente os temas supracitados, de toda maneira, é mister salientar, sob holofotes da ética negativa, que o ato suicida nem sempre está atrelado ao fracasso da vida (2011, p. 58), da mesma forma que a procriação resultaria de um ato supremo de manipulação, causando prejuízos àqueles que vêm ao mundo sem sequer terem o direito de recusar. ${ }^{3}$

Do ponto de vista estrutural, nascemos sem nenhum tipo de valor e, nesse aspecto, não percebemos tantas diferenças da ética negativa com a genealogia da moral nietzschiana. Ambas concordam que a moral consiste num produto histórico forjado pela cultura, igualando proporcionalmente os seres humanos em direitos e reprimindo aqueles julgados inferiores aos intentos da valoração dominante. "Todos os valores que levam à desigualdade provêm de invençôes intramundanas." (CABRERA, 2013, 149). A justificativa de violar os direitos alheios ou a de acentuar desigualdades estaria legitimada numa invenção de além mundos, de modo que a moral seja vista como um conjunto de valores universais.

A solução de Cabrera, no entanto, está na proposta de criar uma "inviolabilidade negativa” que negue qualquer argumento disposto a legitimar a desigualdade, considerando estarmos despidos de um sentido ôntico, que outrora falsamente nos via como seres destinados a uma vida afirmativa e universalizante. Diferentemente disso, caso reconheçamos a verdadeira condição humana, ou seja, a inexistência de valores estruturais em nossas vidas e da consequente igualdade negativa entre todos nós, chegaríamos à clareza de jamais responsabilizarmos os outros pela ausência de algum valor afirmativo. Atribuir responsabilidade direta ou indireta àqueles divergentes dos nossos princípios tende a, equivocadamente, corroborar diferentes formas de perseguição, repressôes e extermínios.

A ética negativa reivindica o princípio do direito e da igualdade entre as pessoas, independentemente das origens econômicas, de gênero, credo ou raça. Obviamente, não há diferença com os princípios éticos tradicionais,

\footnotetext{
$3 \mathrm{O}$ estudo da ética negativa leva a intrigantes desdobramentos, como os temas do suicídio e do nascimento, devidamente explorados em outras obras do autor. Por razóes de delimitação, o interesse do artigo restringiu-se apenas a citá-las, embora saibamos o valor que representam para aquilo que Cabrera chama de "filosofar desde o Brasil".
} 
mas a vantagem disso, segundo Cabrera (2013, p. 152), encontra-se na circunstância de a base negativa assumir a inexistência de valores estruturais na condição humana. Destituído da cobertura ontológica, o ser humano evitaria o sentido absoluto da ética universal, sendo mais consciente daquilo que tange à defesa da inviolabilidade alheia, já que não se reconhece enquanto ser estruturalmente diferente de nenhum outro.

Ao longo da tradição, as éticas afirmativas procuraram resposta para solucionar o problema da desigualdade entre os homens, contudo, as bases religiosas e metafísicas do passado, indubitavelmente, inviabilizam o verdadeiro olhar de igualdade e de acolhimento. Assim, é impossível qualquer valoração afirmativa que iguale ao mesmo tempo todas as pessoas, com suas complexidades e controvérsias. Somente na radical falta de valor acharemos o fundamento da igualdade e da inviolabilidade, haja vista, dessa forma, o homem desvincular-se das ideias totalizantes, geralmente arbitrárias, quando diante de outros tipos de valoração.

\section{Consideraçóes FinaIs}

Percorrermos os principais pontos da Filosofia de Cabrera, revelando os supostos problemas de as academias brasileiras renegarem o pensar desde o Brasil. Em seguida, procuramos analisar a "ética negativa", na esperança de consolidarmos definitivamente a existência de filosofias autóctones sulamericanas, a partir dos brasileiros. A novidade dessa proposta são as condições do aberto e irrestrito diálogo junto à Filosofia dos pensadores europeus, podendo, conforme demonstrado, concordar ou rivalizar com as suas diferentes proposiçóes. A ideia de um comportamento reverso aos princípios de uma moral aristotélica ou kantiana, por exemplo, sugere o enaltecimento de uma postura deflacionante, disposta a mitigar as angústias e os sofrimentos ocultados dos modelos éticos afirmativos. As vicissitudes oriundas do olhar positivo e tradicional do mundo decorrem da cobrança e da expectativa de um vir a ser incondizente com toda a correta estrutura ontológica de incompletude existencial. Diante disso, não cabe aguardarmos metafisicamente nenhuma autorrealização, pelo claro motivo de estarmos marcados por uma série de ambiguidades, tristezas e desilusóes.

É inegável o pessimismo contido nesse argumento, bem como a influência existencialista da sua reflexão. A eminência dos acontecimentos vividos, aliada à consciência da diferenciação daquilo idealizado no sentido 
prático da existência, propicia o amadurecimento humano, livrando-nos das amarras psicológicas de tornarmo-nos algo que dificilmente conseguiríamos ser. Por mais consistente que sejam as ideias de Cabrera, aparentemente ficam, ao nosso ver, algumas questôes sem respostas. Enfrentar a tradição, subvertendo-nos através da visão do mundo pessimista, não constituiria outro modo do vir a ser negado, na sua Filosofia? Partindo da explicação de que o ser representa aquilo que pretendemos nos tornar, mesmo a radicalização da postura pessimista de Cabrera não afirmaria a estrutura ontológica já apresentada por certos filósofos, como Nietzsche e Heidegger? A propósito, em muitos momentos, a ética negativa aparenta uma inclinação maior com uma ontologia, ao invés de detalhar os aspectos que possam configurá-la como um estudo normativo e alternativo, para lidarmos conosco e com os outros.

Nesse ponto, diríamos haver poucas novidades em relação à filosofia heideggeriana, pois também é certo, para o filósofo alemão, o quanto o homem, que se vê aniquilado pelo cotidiano e apontado para o vazio da existência, se sente um ser-para-a-morte. Questionamos se Heidegger, especialmente o de Ser e Tempo, não seria um filósofo negativo, tornando-se idêntico ao tipo negacionista de Cabrera. Da mesma forma, Nietzsche, em Humano, demasiado humano, define na ideia de "espírito livre" alguém cuja consciência lhe favorece o poder de tratar das questóes existenciais, tornando-o potencialmente criador de novos valores (NIETZSCHE, 2012, prólogo, 6).

Convenhamos que o exercício da liberdade de espírito leva o indivíduo a postular valores que cumpram a necessidade do seu crescimento de potência, consciente de que viver nem sempre significa atender às expectativas daqueles que amamos. Todavia, sabendo estar próximo da tipologia nietzschiana, Cabrera, ao que parece, visualiza outra figura humana de pretensóes mais praticáveis. Sua intenção é equiparar os homens em desvalia, facilitando, dessa maneira, a adoção de alguns princípios basilares, como o respeito à inviolabilidade, dado o caráter estrutural da condição humana constituir-se de erros, do sofrimento e da morte.

Enfim, Cabrera consegue ir além da preocupação de Schopenhauer, Nietzsche e Heidegger, trazendo a novidade do "outro" como aquele que sofre pelas mesmas condiçóes estruturais que o igualam a todos os seres humanos. Acreditamos que essa concepção atenda ao objetivo de inserir um novo ethos capaz de substituir o referencial religioso e afirmativo acerca do valor da vida humana. As ideias do filósofo latino atestam a robustez da "Filosofia desde o Brasil" e das suas contribuiçóes para aprendermos a pensar 
além de nossas próprias fronteiras. Assim como alguns nomes do passado, a filosofia cabreriana serve de embriáo, a fim de ajudar a florescer novos pensamentos no Hemisfério Sul. Quem sabe, especialmente prestando-se de suficiente encorajamento a muitos acadêmicos brasileiros presos ao trabalho exegético e, por isso, dispostos a partir do presente e a utilizarem as próprias forças, ainda que de começo se sintam temerosos, por causa dos riscos da rejeição ou do esquecimento.

COSTA, A. L. F. South American reflections: in defense of philosophy below Ecuador. Trans/Form/Açáo, Marília, v. 45, p. 357-378, 2022. Edição Especial.

\begin{abstract}
With the help of the academic Julio Ramon Cabrera, this article develops the study of a Philosophy from Brazil, dividing into three moments: first, the denounce it against the paralyzing effects caused starting by European colonization, having thus hampered philosophical activity for a long time in Latin American countries; second, the exposure of theoretical elements which are able to deconstruct the Eurocentric vision of Philosophy and the last one, the presentation of Cabrera's "negative ethics" as a model of a thinking beyond regionalism. The purpose of this investigation is to corroborate the feasibility of autochthonous productions, whose quality of Brazilian academic research guarantees, without any doubts, a fruitful dialogue with philosophers already consecrated in the western tradition.
\end{abstract}

Keywords: Brazil. Cabrera. Colonization. Negative ethics. Philosophy.

\title{
REFERÊNCIAS
}

ASSIS, Machado. Memórias póstumas de Brás Cubas. São Paulo: Abril, 2010.

CABRERA, Julio Ramon. A ética e suas negaçóes: não nascer, suicídio e pequenos assassinatos. Rio de Janeiro: Rocco, 2011.

CABRERA, Julio Ramon. Diário de um filósofo no Brasil. 2. ed. Ijuí: Unijuí, 2013.

CABRERA, Julio Ramon. Europeu não significa universal. Brasileiro não significa nacional. Nabuco: revista brasileira de humanidades, Belo Horizonte, n. 2, p. 1-46, 2014.

CABRERA, Julio Ramon. Margens das filosofias da linguagem. Brasília: Editora da UnB, 2009.

DELEUZE, Gilles; GUATTARI, Félix. O que é filosofia? 2. ed. Trad.: Bento Prado Jr. e Alberto Alonso Muńoz. Rio de Janeiro: Editora 34, 2005. 
GOMES, Roberto. Crítica da razão tupiniquim. Curitiba: Criar, 2008.

HEIDEGGER, Martin. Ser e tempo. Trad.: Marcia de Sá Cavalcante. Parte I. Petrópolis: Vozes, 1988.

JAIME, Jorge. Diário de um filósofo no Brasil. In: JAIME, J. Temas filosóficos, Rio de Janeiro, 2003.

LOOSE, John. O homem e a ciência: introdução histórica à filosofia da ciência. Trad.: Borisas Cimbleris. Belo Horizonte: Itatiaia, 2000.

MARCONDES, Danilo. Iniciaçáo à história da Filosofia: dos pré-socráticos a Wittgenstein. Rio de Janeiro: Jorge Zahar, 2007.

MELO SOBRINHO, Noéli. Apresentação In: NIETZSCHE, F. W. Escritos sobre educaçáo. Tradução de Noéli C. M. Sobrinho. Rio de Janeiro/São Paulo: PUC-Rio/ Loyola, 2003. p. 7-47.

NIETZSCHE, Friedrich. Humano, demasiado humano. Trad.: Paulo César de Sousa. São Paulo: Companhia de Bolso, 2012.

OSPINA, William. Pa que se acabe la vaina. Bogotá: Planeta, 2013.

Recebido: $14 / 8 / 2020$

Aceito: 28/01/2021 